\title{
Low Impact Development (LID) as an effort to achieve a sustainable urban drainage system (SUDS). Case Study: Left Side Of Garang River Segment VI Semarang
}

\author{
Anik Sarminingsih ${ }^{1 *}$, Ganjar Samudro ${ }^{1}$, Aisyatul Mas'adah ${ }^{1}$ \\ ${ }^{1}$ Department of Environmental Engineering, Diponegoro University, Semarang - Indonesia
}

\begin{abstract}
The Garang River functions as a flood controller and a source of raw water for drinking water. This river is divided into seven segments, and in the downstream segment VI there is intake of raw water for drinking water. The land use is dominated by built-in land, in the form of dense settlements and industrial estates. This study aims to evaluate the condition of the drainage system, both in terms of runoff and water quality, and apply the concept of LID to achieve a sustainable drainage system. The method used is the SWMM. Evaluations were carried out in three outlets. In existing conditions, channel capacity in general is still sufficient, while water quality does not meet effluent standard quality for observed parameters including TSS, BOD, COD, oil \& fat parameters and Total coliform. The LID concept that are suitable are Bio retention cell, Permeable Pavement and Rooftop disconnection. The use of this type of LID is significant enough to reduce runoff by $77 \%$ at outlet $1,98 \%$ at outlet 2 and $73 \%$ at outlet 3 and decrease in some parameters of water quality by $77 \%$ to $100 \%$.
\end{abstract}

Keywords: Garang river; drainage; sustainable; LID; SWMM

\section{Introduction}

To support the planning and implementation in the fields of energy, environment, epidemiology and information systems in response to the development of the industrial revolution 4.0, this study was made. The topic of this study discusses environmental management in urban areas that directly affects water quality, flooding, and in turn affects the level of health, safety and comfort of the community.

The development of the region followed by changes in the function of land cover from non-building land to built land both as residential, industrial and other uses will greatly affect surface runoff. The existence of a drainage system in urban areas is an an absolute necessity [1]. The planning of convensional drainage system often have not considered changes in runoff coefficients that have changed rapidly, and have not taken into account water quality problems. For this reason, a sustainable drainage system is needed that takes into account the sustainability of ecosystems that can reduce runoff and concentration of pollutants in water bodies.

The Garang River in the city of Semarang is the main water body of the drainage system in the Garang watershed. Based on Central Java Governor Regulation No. 156 of 2010 concerning Water Allocation and Management of Garang River Water Quality, Garang River is divided into 7 segments based on consideration of previous and future water use, topography, river morphology, potential water sources, and potential sources of pollutants. The top portion of the Garang watershed is segment I, while segment VII is the most downstream segment. In the downstream segment VI or upstream in segment VII, Garang River water is used as a source of raw water for drinking water by the Semarang Municipal Water Company (PDAM).

To maintain river water quality, one of the things that can be done is evaluating the quality of water from the channels that enter the Garang River. As a case study, the left side of the Garang River segment VI includes the villages of Kalipancur, Desa Manyaran, Desa Ngemplak Simongan, and Desa Gisikdrono. The four villages are part of the Garang watershed which is a densely populated area and industrial area.

Drainage channels in this area serve to drain rainwater and domestic wastewater with a mixed system.

From the results of monitoring carried out by the Central Java Environment and Forestry Service (DLHK) in the VI segment of the Garang River in 2013 to 2017, water pollution parameters that exceed the quality standards are TSS, BOD, COD, nitrate, sulfur as $\mathrm{H} 2 \mathrm{~S}$, chlorine free, chrome (IV), fluoride, oil and fat, fecal coliform, and total coliform.

One software that can be used to simulate water quality conditions and existing management efforts is EPA SWMM. EPA SWMM (Environmental Protection Agency, Storm Water Management Model) is a model used to plan, analyze, and design models related to rainwater runoff and drainage systems in urban areas. SWMM is a dynamic simulation model of the relationship

\footnotetext{
* Corresponding author: anikharieka@gmail.com
} 
between rainfall and runoff $[2,3]$. This model is used to simulate single rainfall events or time series, both in the form of runoff volume and water quality, especially in urban areas.

\section{Purpose of the Study}

This paper aims to present the results of the study of the effect of using the Low Impact Development (LID) concept on runoff and quality of drainage system wastewater using the SWMM model. Various alternative types of LID are evaluated based on conformity with the location of the study area. The impact of using LID besides being used to evaluate surface runoff also evaluates water quality, especially parameters of $\mathrm{pH}$, BOD, COD, TSS, oil and fat, and total coliform which represents physical, chemical, and microbiological characteristics of water pollution.

\section{Method of Study}

The research phase is conducting literature studies on the method of sustainable drainage systems that implement LID in various developed countries, studying the condition of the current study area, conducting an analysis of sustainable drainage system methods, comparing and selecting a sustainable drainage system method with the choice of LID suitable for the region current study

In this study, the analysis phase is divided into three stages, according to the analytical method in the EPA SWMM (Environmental Protection Agency Storm Water Management Model) [4]. Basically, in the SWMM model there are three stages of analysis, namely:

1. Hydrological analysis, which is the analysis of rain data in a catchment area.

2. Hydraulics analysis, which is the analysis of water movement in the channel.

3. Analysis of water quality, namely pollutants originating from the catchment area according to land cover.

\subsection{Hydrological Analysis}

\subsubsection{Areal rainfall calculation}

Calculation of average rainfall was done by processing rain data that was obtained from each rain gauge station. Observed hourly rainfall was used as a pattern of time series daily rainfall.

\subsubsection{Calculation of Surface Runoff}

SWMM can convert excess rainfall into a surface flow. SWMM is a distributed model, so it allows a study area to be divided into several sub-catchments to get the best results based on differences in topography, drainage lines, land cover, and soil characteristics. Therefore, runoff is calculated in each sub-catchment [2]. The equation used is:

$$
Q=\frac{1,49}{n} S^{1 / 2} R_{x}^{2 / 3} A_{x}
$$

where:

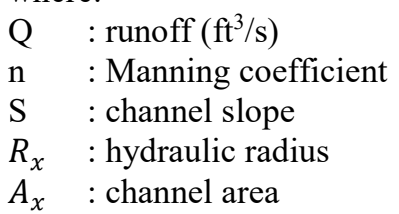

\subsection{Hydraulics Analysis}

SWMM Hydraulics solves one-dimensional flow problems, varying flow, unsteady flow along the channel to determine water level, flow rate, flow depth at all times. There are two analytical methods used in SWMM, namely dynamic wave analysis and kinematic wave analysis.

Dynamic wave analysis uses the St Venant equation to produce the most theoretically accurate results. This analysis model describes channel storage, backwater effects, flow in culverts, the flow of bends, and pressurized flow. This analysis was chosen for areas that experienced significant backwater due to downstream flow restrictions [3]. The $S_{f}$ value in this analysis is obtained based on the Manning equation:

$$
S_{f}=\left(\frac{n}{1,486}\right)^{2} \frac{Q|U|}{A R^{4 / 3}}
$$

where:

$\mathrm{n} \quad$ : Manning roughness $\left(\mathrm{s} / \mathrm{m}^{1 / 3}\right)$

$\mathrm{R} \quad$ : hydraulic radius ( $\mathrm{ft}$ )

$\mathrm{U} \quad$ : velocity $(\mathrm{Q} / \mathrm{A})(\mathrm{ft} / \mathrm{s})$

1,486: conversion factor from $\mathrm{m}^{1 / 3}$ to $\mathrm{ft}^{1 / 3}$

Kinematic wave analysis solves continuity equations with a simple form of momentum equations in each channel. This analysis model cannot explain the backwater effect, flow in culverts, bend flow, and pressure flow. This analysis is applied to steep channels $(>10 \%)$ with high-speed shallow flows [3]. The value $\mathrm{S}_{0}$ $=\mathrm{S}_{\mathrm{f}}$ is obtained by the equation:

$$
Q=\frac{A R^{2 / 3} \sqrt{S_{0}}}{\mu}
$$

\subsubsection{Water Quality Analysis}

The process that can be modeled regarding water quality using SWMM is as follows [5]:

1. Pollution of dry season pollutants

2. Flow during the rainy season containing pollutants from certain land uses

3. Flow from rainfall

4. Sanitation flow in the drainage system

5. Movement of water quality through the drainage system

6. Reducing the concentration of water quality through treatment in storage units or natural processes in the canal

Water quality simulation in SWMM has 2 ways. The first way is to collect calibration data to calibrate the model equations used for quality simulation. The second method is using EMC (Event Mean Concentration) to calculate the pollution load value [6]. 
The accumulation of each pollutant that accumulates based on land cover is explained by mass per unit area or per unit length of road. For microbes, the number of organisms is used instead of mass. Because there is no proper function in explaining pollutant stacks, SWMM provides three different function choices for each constituent combination and land use, namely power function, exponential, and saturation [6].

The equation used to calculate the amount of pollutant stacks is:

1. Power function

$b=\operatorname{Min}\left(B_{\text {max }}, K_{B} t^{N_{B}}\right)$

with:

b : pile of pollutants of subcatchment

$\mathrm{t} \quad$ : time interval (day)

$B_{\text {max }}$ : probable maximum pile of pollutants

$K_{B} \quad$ : constant of stack rate

$N_{B} \quad$ : exponent of time

2. Exponential

$$
b=B_{\text {max }}\left(1-e^{-K_{B} t}\right)
$$

3. Saturation

$$
b=B_{\max } t /\left(K_{B}+t\right)
$$

The main object used in the analysis of water quality in SWMM is pollutant and land use. Information needed for each polluter includes the name of the pollutant, unit concentration (i.e., milligrams/liter, microgram/liter, or amount/liter), concentration in rainfall, concentration in groundwater, and concentration in direct infiltration. Land use is a category of development activities or land surface characteristics defined for sub-trajectories. Examples of land use activities are housing, commercial, industrial, and undeveloped. SWMM users have many options to define land use and assign it to the sub-area.

In calculating pollutant flow, SWMM uses 3 methods, namely exponential wash off, rating curve wash off, and event mean concentration (EMC) wash off [7]. The equation used in exponential wash off is:

$$
w=K_{w} q^{N_{w} m_{B}}
$$

where:

w : pollutant loads $(\mathrm{mg} / \mathrm{hr})$

$K_{w} \quad$ : wash off coeff. $(/ \mathrm{m})$

$\mathrm{q}:$ flow rate (in/hr)

$m_{B}$ : the initial mass of constituents on the surface

$N_{w}$ : wash off exponent

The EMC value is usually measured by laboratory analysis of the sample. EMC is the most commonly used parameter to estimate nonpoint pollution loads in SWMM and most other models [1]

$$
w=K_{w} q f_{L U} A
$$

where:

W : pollutant loads $(\mathrm{mg} / \mathrm{hr})$

$K_{w}:$ EMC x flow $(\mathrm{mg} / \mathrm{s})$

q : flow rate

$f_{L U}:$ sub catchment fraction based on land use

A : area
EPA SWMM is a periodic rainfall-runoff simulation model used to simulate a single occurrence or a continuous occurrence with the quantity and runoff quality of the area under review [8]. The SWMM runoff component is operated by summing the area of the catchment (sub catchment) that receives the total rain and generates it in runoff and pollution load. The runoff flow in SWMM can be traced through piped systems, open drains, catch ponds and pumps. SWMM is the quantity and quality of runoff generated in each catchment area, and the average flow, flow depth and quality of water in each pipeline and open channel during the simulation period are included in additional time [5].

The concept of SWMM is the modeling of the hydrological cycle that exists on earth, this model contains about:

Rainfall modeling. Rain is the most important factor in hydrology. The degree of rainfall is usually expressed by the amount of rainfall in a given time unit and is called the bulk intensity. In SWMM rainfall is described as Rain Gage symbol to represent rain to be simulated.

Soil surface modeling which is represented in this case by a Subcatchment symbol. The soil surface receives rainfall from the atmosphere then some water will seep into the soil as infiltration and some will become surface runoff.

Groundwater modeling, through the infiltration process, receives water from the surface. In the SWMM symbolized by the Aquifer symbol.

Modeling of the water transport network. Water is channeled through canals, canals, pipes, then can also be simulated about the use of pumps, storage ponds, and waste treatment. In SWMM this section is symbolized as Node and Link.

Modeling as mentioned above is assembled into a single unit that describes a drainage system[9]. Pictures and sequences can be seen in Fig. 1.

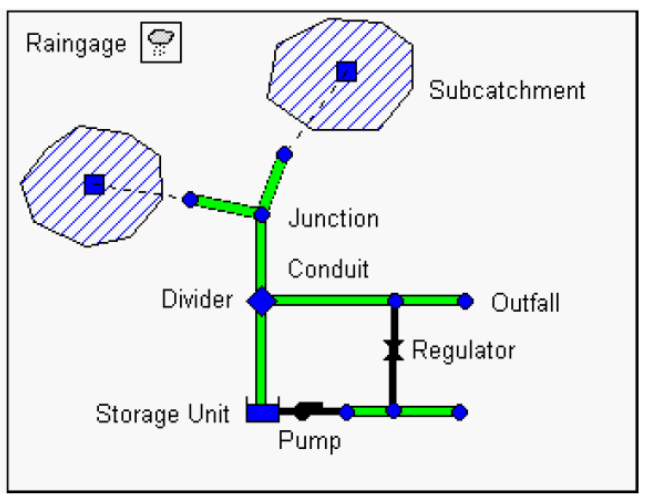

Fig. 1. Modeling the drainage system on SWMM

\subsection{LID (Low Impact Development)}

LID (Low Impact Development) is a small-scale management concept of a rainwater drainage system, which starts from the source of the problem so that the negative effects of urban runoff can be controlled [6]. LID is planned to be able to filter waste, control the flood water level, the volume of floodwater that will be released into 
the downstream area and maintain the base flow. There are several types of LID, including [10]:

- Bio-retention cell, which is a technology that combines plant elements in a landscape with a layer of gravel to maximize water absorption into the soil.

- The rain garden, which is a type of bio-retention cell that only uses a layer of soil without using a layer of gravel beneath it.

- Green roofs, another type of bio-retention cell that uses a layer of soil on the roof.

- Infiltration trenches, which are narrow trenches that are filled with gravel to inhibit runoff from waterresistant areas to provide a storage volume and additional time for runoff to be absorbed into the soil.

- Permeable pavement, which is a paving block that is placed on a stretch of gravel or sand.

- Vegetative swales, which are channels with sloping sides covered in grass and other plants to slow down the transport of runoff and allow more time to seep into the soil.

\subsection{Tools and Material}

Tools and material which are used in this research consist of [11]:

- Rainfall data were collected from several rainfall stations around the location,

- The drainage system and geometric data of drainage channels

- Land-use maps

- Water quality data, which is taken at the same time as rain event data.

\subsection{Study Field Description}

Garang watershed is a cross-district watershed which covers the City of Semarang, Semarang Regency, and Kendal Regency. The Upper Garang River plays an important role in accommodating surface water runoff as well as functioning as a conservation area, while the downstream part is used as a raw water source for Semarang City and as a canal that accommodates regional drainage channels in [4]. Based on the Central Java Governor Regulation No 156 of 2010 concerning Water Allocation and Management of Garang River Water Quality, Garang River is divided into 7 segments. Garang River upstream (segment I, segment II, and segment III) there are forests and coffee plantations, agriculture, settlements, food/beverage packaging industries, hotels and hospitals. Whereas in the Kreo River (segment IV and segment V) there are settlements and Jatibarang Final Disposal Sites which have the potential to reduce water quality because the leachate is produced. The meeting segment between the upper Garang River and Kreo River, which is around Tugu Suharto up to Simongan Dam (segment VI), contains domestic waste, agricultural waste, and industrial waste. In the VI segment, there is a drinking water intake by the Semarang Municipal Water Company.

The topography of the study area consists of the northern lowlands and rises to the south, with slopes ranging from $2-5 \%$. Based on data from the National Disaster Management Agency, this region is classified as a flood-prone area.

The drainage system in the study area is currently still using a conventional drainage system, which is transferring surface runoff as quickly as possible to the drainage canal. The channel dimension with a width between $0.50 \mathrm{~m}$ to $1.2 \mathrm{~m}$ and a depth between 0.6 to 1.0 $\mathrm{m}$ also has the potential for a runoff if high-intensity rain occurs.

Land use includes built-up land, fields/gardens, ponds, rice fields, and other uses. Of the total land area of $1862.86 \mathrm{ha}$, the largest land use is built-up area of 1329.25 ha $(71.35 \%)$, while the smallest land use is rice fields of 8 ha $(0.43 \%)$. The location map of the study area in the Garang watershed system is presented in Figure 2.

\subsection{Drainage System Modeling}

In the SWMM model, the first step is to make a drainage system map according to existing conditions. In making maps, use the help of images from Google Earth to adapt to existing conditions. In the drainage system in the study area, an evaluation of runoff discharge and pollutant concentrations was carried out in three observation points, namely Outlet 1, Outlet 2 and Outlet 3, which all of these outlets lead directly to the Garang Segment VI river. The map of the drainage network system used in the SWMM model can be seen in Fig. 3.

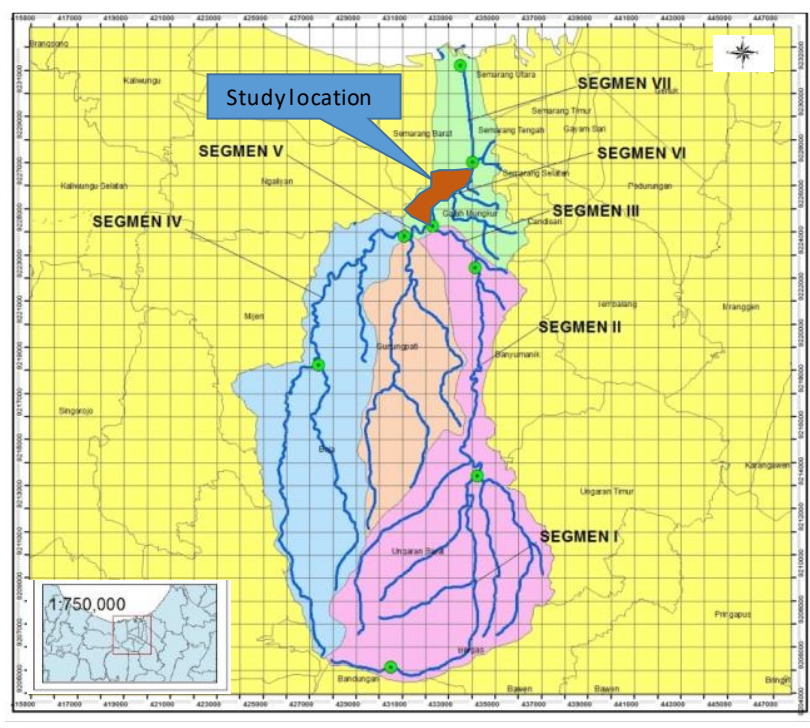

Fig. 2. Map of Studi Location on Garang Watershed

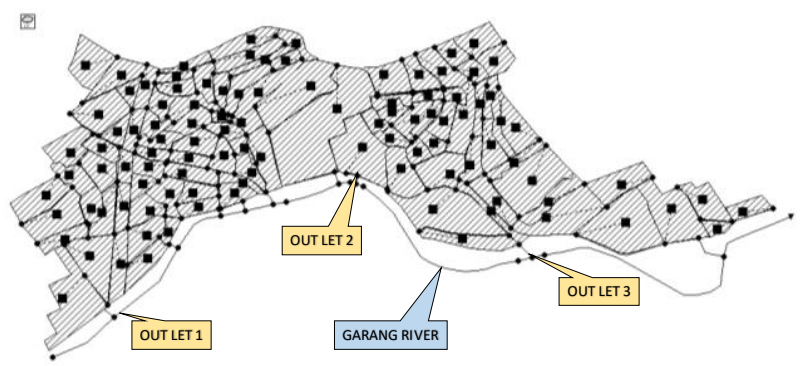

Fig. 3. Modeling the drainage system using SWMM in the left side of Segment VI of Garang River 


\subsection{Model Simulations}

The model simulation is used in two scenarios. The first scenario is the input of rain data used are rainfall data, land cover and water quality parameters observed. The second scenario is with the same rainfall data input, but in the land parameter, the LID option is added.

In the first scenario, validation is carried out first to get the theoretical pollutant concentration that approaches the pollutant concentration observed by conducting a trial and error in the EMC (Event Mean Concentration) value. In Indonesia, there has been no research on the EMC magnitude that is following the conditions of the land, for that the EMC value is tested based on the EMC magnitude of various countries as shown in Table 1.

Using rain data and EMC values obtained in the first scenario, and by adding LID options, the impact can be evaluated on changes in runoff discharge and pollutant concentration in the channel.

Table 1. EMC Value in Land Use [12]

\begin{tabular}{|l|l|l|r|r|r|r|}
\hline No & $\begin{array}{c}\text { Paramet } \\
\text { er }\end{array}$ & Unit & $\begin{array}{c}\text { Residenti } \\
\text { al }\end{array}$ & $\begin{array}{c}\text { Comerci } \\
\text { al }\end{array}$ & $\begin{array}{r}\text { Industr } \\
\text { y }\end{array}$ & Open \\
\hline $\mathbf{1}$ & BOD & $\mathrm{mg} / 1$ & $10^{1)}$ & $9,3^{1)}$ & $7,8^{1)}$ & $4^{5)}$ \\
\hline $\mathbf{2}$ & COD & $\mathrm{mg} / 1$ & $54,5^{3)}$ & $58^{3)}$ & $146,2^{4)}$ & $36^{4)}$ \\
\hline $\mathbf{3}$ & TSS & $\mathrm{mg} / 1$ & $49^{3)}$ & $43^{3)}$ & $81^{3)}$ & $48,5^{3)}$ \\
\hline $\mathbf{4}$ & Oil\&Fat & $\mathrm{mg} / \mathrm{l}$ & $4^{3)}$ & $4,6^{3)}$ & $4,8^{3)}$ & $1,3^{3)}$ \\
\hline $\mathbf{5}$ & Amonia & $\mathrm{mg} / 1$ & $0,31^{3)}$ & $0,5^{3)}$ & $0,42^{3)}$ & $0,09^{2)}$ \\
\hline $\mathbf{6}$ & $\begin{array}{l}\text { Total } \\
\text { coliform }\end{array}$ & $\begin{array}{c}\mathrm{Jml} / 10 \\
0 \mathrm{ml}\end{array}$ & $19113^{6)}$ & $19113^{6)}$ & $19113^{6}$ & $\begin{array}{r}19113 \\
6\end{array}$ \\
\hline
\end{tabular}

Source: ${ }^{1)}$ EPA, 1983; ${ }^{2)}$ Ackerman and Schiff, 2003; ${ }^{3)}$ Maestre and Pitt, 2005; ${ }^{4)}$ Ellis and Mitchell, 2006; ${ }^{5)}$ Chow, 2012; ") DDOEIP, 2014

\subsubsection{Existing Conditions}

In the existing condition or the first scenario, it is used the rain data at the time of sampling which is on March 5, 2019, which is one day before the water sampling at the Jatibarang rain station is located in the Kreo subwatershed. The rainfall data used is $7.76 \mathrm{~mm}$. The rainfall is then converted into hourly rainfall using an hourly rain pattern from the Silandak rain station which is located near the study location. Rainfall distribution often occurs for 3 hours as shown in Table 2

Table 2 Time Series rainfall data

\begin{tabular}{|c|c|c|c|c|}
\hline No & Time & $\begin{array}{c}\text { Hourly } \\
\text { rainfall } \\
(\mathrm{mm})\end{array}$ & $\begin{array}{l}\text { Daily } \\
\text { (mm) }\end{array}$ & $\begin{array}{c}\text { Time Series } \\
(\mathrm{mm})\end{array}$ \\
\hline 1 & 1 & 1 & \multirow{4}{*}{7,76} & 1,109 \\
\hline 2 & 2 & 4 & & 4,434 \\
\hline 3 & 3 & 2 & & 2,217 \\
\hline & Total & 7 & & \\
\hline
\end{tabular}

The results of the SWMM model simulation obtained an EMC value that is following the conditions of the study area as shown in Table 3. The EMC values obtained in this study are different from the reference EMC values. This is due to differences in land characteristics, amount and frequency of rainfall, and content in rainwater (EPA, 1983) [6]. This EMC value is the result of the trial-error test concerning the EMC value from Table 1 so that the value of the pollutant concentration model approaches the pollutant concentration value of the research results.

Table 3. EMC Values in the study location

\begin{tabular}{|l|c|r|r|r|r|}
\hline $\begin{array}{c}\text { Paramete } \\
\mathbf{r}\end{array}$ & Unit & $\begin{array}{c}\text { Residentia } \\
\mathbf{l}\end{array}$ & $\begin{array}{c}\text { Commerci } \\
\text { al }\end{array}$ & $\begin{array}{c}\text { Industr } \\
\mathbf{y}\end{array}$ & Open \\
\hline BOD & $\mathrm{mg} / 1$ & 7,3 & 9,3 & 41,4 & 4 \\
\hline COD & $\mathrm{mg} / 1$ & 23,8 & 58 & 131,5 & 36 \\
\hline TSS & $\mathrm{mg} / 1$ & 50,7 & 43 & 73,3 & 48,5 \\
\hline Oil\&Fat & $\mathrm{mg} / 1$ & 5,1 & 4,6 & 12 & 1,3 \\
\hline Ammonia & $\mathrm{mg} / 1$ & 0,0062 & 0,007 & 0,009 & 0.0035 \\
\hline $\begin{array}{l}\text { Total } \\
\text { coliform }\end{array}$ & $\begin{array}{c}\mathrm{N} / 100 \\
\mathrm{ml}\end{array}$ & 15 & 11000 & 80000 & 15000 \\
\hline
\end{tabular}

The results of the model validation show the concentration of the model approaching the concentration of the results of the study. The concentration value of the model used the time-matched data with observational data, namely at the seventh hour after the rain occurred. Graph of the amount of discharge and water quality at outlet 1, outlet 2 and outlet 3 are shown in Fig. 4.

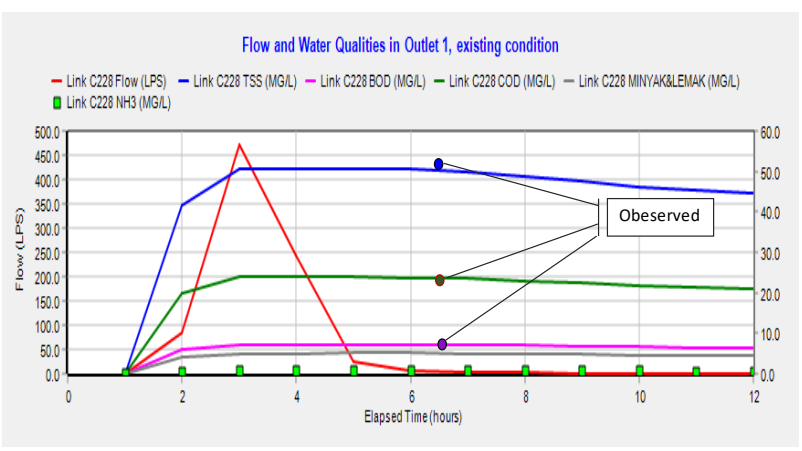

(a)

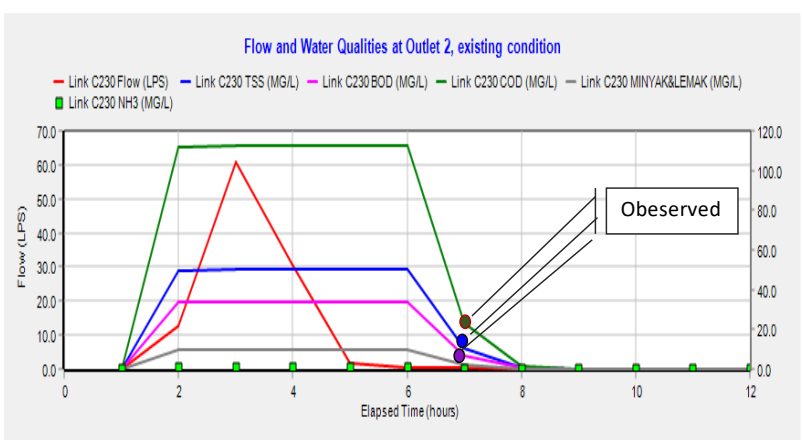

(b)

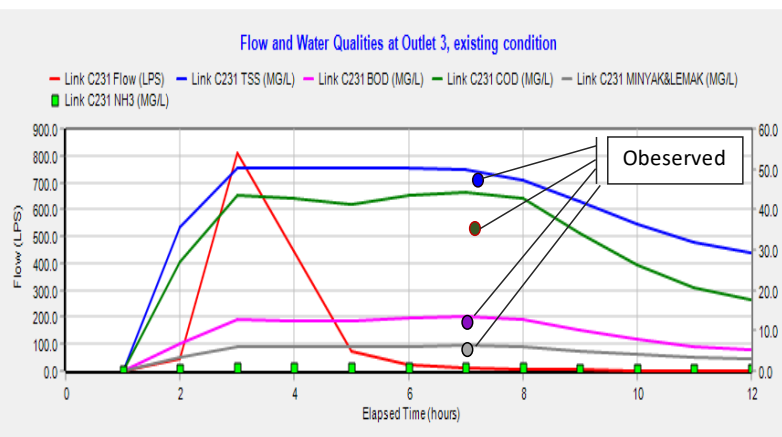

(c)

Fig. 4. Flow and Water Qualities in existing condition at Outlet 1 (a), Outlet 2 (b) and Outlet 3 (c) 
Based on the research data in the three outlet drainage channels, for several water quality parameters including TSS, BOD, COD, Oil \& fat and coliform total exceeding the maximum level allowed by PP No. 82 of 2001 for class 1 river water. Only the ammonia parameter still meet the quality standards, this is because there is no agricultural activity in the location which is the biggest contributor to ammonia for the waters.

\subsubsection{LID}

Considering the condition of water quality in the drainage channel that exceeds the quality standard and to reduce runoff to the main discharge, control is needed where the proposed alternative is LID. Several choices of LID types include Bio-retention cell, Rain Garden, Green Roof, Permeable Pavement, Infiltration Trenches, Vegetative Swales and Rooftop Disconnection. The first step is to evaluate the condition of the land, soil type, land availability, and current land use.

After finding out the allowance for each type of LID, the author then uses LID permeable pavement, rooftop disconnection, and bio-retention cell types. Permeable Pavement was chosen because it is a type of LID that can be applied to the study location. Study locations in this study are Manyaran Village, Ngemplak Simongan Village, and Gisikdrono Village, which are densely populated areas. LID types of rooftop disconnections can be applied if residents add pipes to their roof so that the roof of the house has channels that channel rain water to water catchment areas. Bio-retention cell was chosen because it is a type of LID that can be applied to the study location, namely by changing the type of existing drainage channel into a channel that can absorb more runoff.

The characteristics of the three LIDs are proposed as shown in Table 4.

Table 4. Characteristics of the LID used

\begin{tabular}{|c|c|c|c|c|c|c|}
\hline \multirow[t]{2}{*}{ No } & \multicolumn{2}{|c|}{$\begin{array}{c}\text { Permeable } \\
\text { Pavement }\end{array}$} & \multicolumn{2}{|c|}{$\begin{array}{c}\text { Rooftop } \\
\text { Disconnection } \\
\end{array}$} & \multicolumn{2}{|c|}{$\begin{array}{c}\text { Bio-retention } \\
\text { cell }\end{array}$} \\
\hline & Criteria & Value & Criteria & Value & Criteria & Value \\
\hline 1 & $\begin{array}{l}\text { Surface } \\
\text { roughne } \\
\text { ss }\end{array}$ & $\begin{array}{r}0,02 \\
5\end{array}$ & $\begin{array}{l}\text { Assumpti } \\
\text { ons about } \\
\text { the area of } \\
\text { the } \\
\text { house's } \\
\text { roof }\end{array}$ & $\begin{array}{l}81 \\
\mathrm{~m}^{2}\end{array}$ & $\begin{array}{l}\text { Depth of } \\
\text { surface }\end{array}$ & $\begin{array}{l}150 \\
\mathrm{~mm}\end{array}$ \\
\hline 2 & $\begin{array}{l}\text { Slope } \\
\text { surface }\end{array}$ & $1 \%$ & $\begin{array}{l}\text { Diameter } \\
\text { of pipe }\end{array}$ & $\begin{array}{l}100 \\
\mathrm{~mm}\end{array}$ & $\begin{array}{l}\text { Compari } \\
\text { son of } \\
\text { plant } \\
\text { volume } \\
\end{array}$ & 0,8 \\
\hline 3 & $\begin{array}{l}\text { Type of } \\
\text { paving }\end{array}$ & $\begin{array}{r}\text { Pavi } \\
\mathrm{ng} \\
\text { block } \\
\mathrm{s}\end{array}$ & $\begin{array}{l}\text { Surface } \\
\text { roughness }\end{array}$ & $\begin{array}{r}0,01 \\
1\end{array}$ & $\begin{array}{l}\text { Surface } \\
\text { roughnes } \\
s\end{array}$ & 0,03 \\
\hline 4 & \begin{tabular}{|l} 
Thickne \\
ss of \\
paving
\end{tabular} & $\begin{array}{l}100 \\
\mathrm{~mm}\end{array}$ & $\begin{array}{l}\text { Slope } \\
\text { surface }\end{array}$ & $60 \%$ & $\begin{array}{l}\text { Slope } \\
\text { surface }\end{array}$ & $3 \%$ \\
\hline 5 & $\begin{array}{l}\text { Permea } \\
\text { bility }\end{array}$ & $\begin{array}{r}150 \\
\mathrm{~mm} / \\
\mathrm{hr}\end{array}$ & & & $\begin{array}{l}\text { Depth of } \\
\text { soil }\end{array}$ & $\begin{array}{l}650 \\
\mathrm{~mm}\end{array}$ \\
\hline
\end{tabular}

\begin{tabular}{|c|l|r|l|l|l|c|}
\hline 6 & $\begin{array}{l}\text { Thickne } \\
\text { ss of } \\
\text { soil }\end{array}$ & $\begin{array}{r}200 \\
\mathrm{~mm}\end{array}$ & & & Porosity & 0,52 \\
\hline 7 & Porosity & 0,35 & & $\begin{array}{l}\text { Field } \\
\text { capacity }\end{array}$ & 0,15 \\
\hline 8 & $\begin{array}{l}\text { Conduc } \\
\text { tivity }\end{array}$ & $\begin{array}{r}130 \\
\mathrm{~mm} / \\
\mathrm{hr}\end{array}$ & $\begin{array}{l}\text { Wilting } \\
\text { point }\end{array}$ & 0,08 \\
\hline 9 & $\begin{array}{l}\text { Thickne } \\
\text { ss of } \\
\text { storage }\end{array}$ & $\begin{array}{r}300 \\
\mathrm{~mm}\end{array}$ & & & $\begin{array}{l}\text { Thicknes } \\
\text { sof } \\
\text { storage }\end{array}$ & $\begin{array}{l}200 \\
\mathrm{~mm}\end{array}$ \\
\hline
\end{tabular}

Changes in the amount of runoff and water quality in the three outlets under conditions before there are LIDs and after LIDs are shown in Table 5.

Table 5. Changes the runoff and water quality

\begin{tabular}{|c|c|c|c|c|c|c|}
\hline $\begin{array}{l}\text { Descrip } \\
\text { tion }\end{array}$ & $\begin{array}{l}\text { Flow } \\
\text { (LPS) }\end{array}$ & $\begin{array}{l}\mathrm{TSS} \\
(\mathrm{Kg})\end{array}$ & $\begin{array}{l}\text { BOD } \\
(\mathrm{Kg})\end{array}$ & $\begin{array}{l}\mathrm{COD} \\
(\mathrm{Kg})\end{array}$ & \begin{tabular}{|l|} 
OIL\&F \\
$\mathrm{AT}$ \\
$(\mathrm{Kg})$ \\
\end{tabular} & $\begin{array}{l}\text { T.COLI } \\
(\log N)\end{array}$ \\
\hline \multicolumn{7}{|c|}{ Outlet $1(\mathrm{CA}=42 \mathrm{Ha})$} \\
\hline $\begin{array}{l}\text { Without } \\
\text { LID }\end{array}$ & 472.61 & 138.8 & 19.81 & 65.8 & 13.762 & 8.916 \\
\hline $\begin{array}{l}\text { With } \\
\text { LID }\end{array}$ & 107.28 & 9.181 & 1.312 & 4.356 & 0.911 & 7.738 \\
\hline$\%$ & $77 \%$ & $93 \%$ & $93 \%$ & $93 \%$ & $93 \%$ & $13 \%$ \\
\hline \multicolumn{7}{|c|}{ Outlet $2(\mathrm{CA}=5 \mathrm{Ha})$} \\
\hline $\mathrm{C} 230$ & 61.01 & 17.93 & 12.16 & 40.29 & 3.534 & 10.38 \\
\hline $\mathrm{C} 230$ & 1.51 & 0.061 & 0.041 & 0.136 & 0.012 & 7.909 \\
\hline$\%$ & $98 \%$ & $100 \%$ & $100 \%$ & $100 \%$ & $100 \%$ & $24 \%$ \\
\hline \multicolumn{7}{|c|}{ Outlet $3(\mathrm{CA}=73.4 \mathrm{Ha})$} \\
\hline $\mathrm{C} 231$ & 823.3 & 245.8 & 61.74 & 209.6 & 29.274 & 10.832 \\
\hline $\mathrm{C} 231$ & 223.4 & 25.12 & 6.982 & 23.97 & 3.096 & 9.943 \\
\hline$\%$ & $73 \%$ & $\begin{array}{l}90 \\
\%\end{array}$ & $89 \%$ & $89 \%$ & $89 \%$ & $8 \%$ \\
\hline Standar & & 50 & 2 & 10 & 1 & 100 \\
\hline
\end{tabular}

The scheme for the three types of LID as shown in Figure 5.

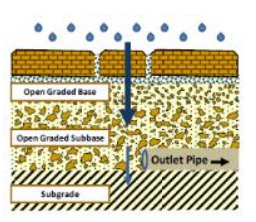

(a)

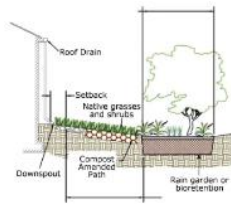

(b)

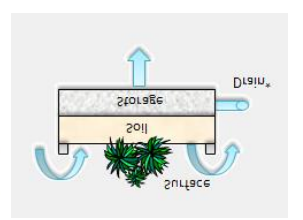

(c)
Fig. 5. Scheme Permeable Pavement (a); Rooftop Disconnection (b); Bio-retention cell (c) [7]

\section{Result and Assessment}

The results of running on the SWMM model presented in Fig. 4 show that when the runoff discharge reaches a peak, the pollutant load also reaches the peak, then it decreases even though the decrease in pollutant load is not as large as the decrease in the runoff. This has also been discussed by several previous studies. Based on research conducted by Borris et al [7] stated that the intensity and higher rainfall will cause higher runoff as well and will affect the washing and mobilization process of pollutants assuming 
the same amount of pollutant sources. However, the longer the pollutant concentration value is getting smaller due to pollutants on land that has been eroded before when it rains.

This is in accordance with Gong et al's statement (2016) [8], that after the rain stopped, runoff did not contain high pollutant concentrations because most pollutants were washed and transported during "first flush" [8]. The first flush is the initial runoff during rain. Generally, pollutants exhibit higher concentrations during the first rain shower [9]. Gong et al (2016) explained that with increasing discharge due to increased rainfall over time, the concentration of first pollutants increases with time and reaches peak values, then decreases over time because the amount of accumulated previous pollutants remaining decreases with time [8].

After running using 3 types of LIDs at once, we found a comparison of the maximum parameter values before and after the control effort with LID can be seen in Fig. 6. While the decrease in runoff is shown in Fig. 7.

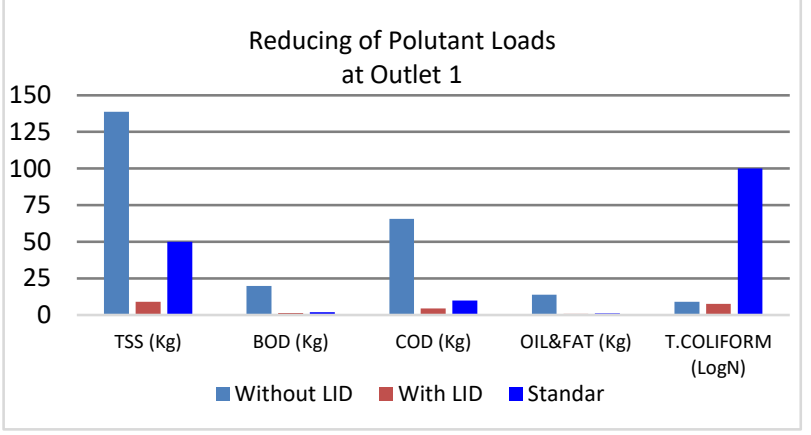

(a)

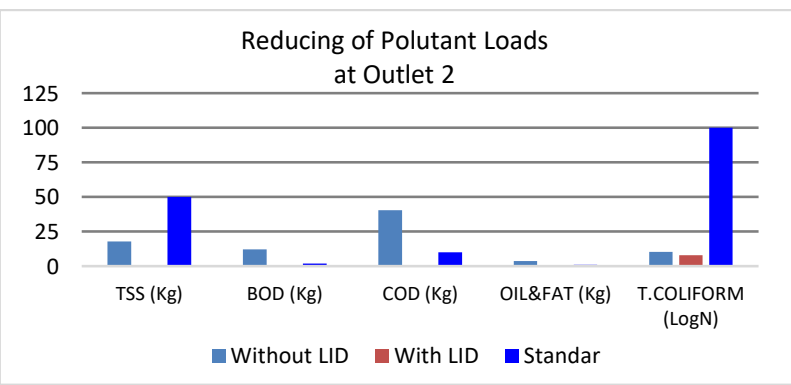

(b)

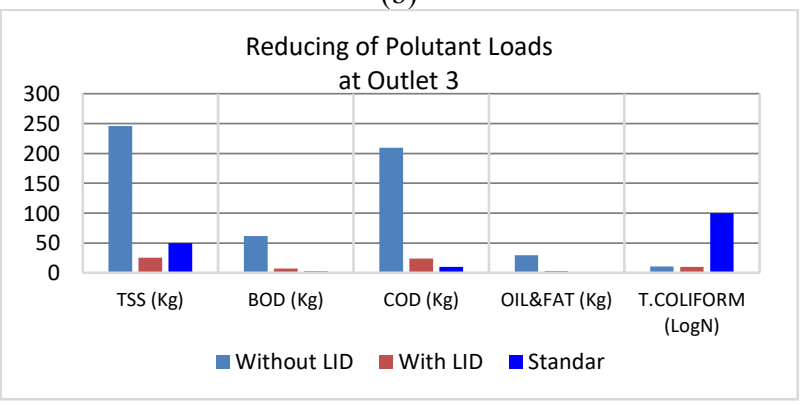

(c)

Fig 6. Reducing Pollutant Load at Outlet 1 (a), Outlet2 (b) and Outlet 3 (c)

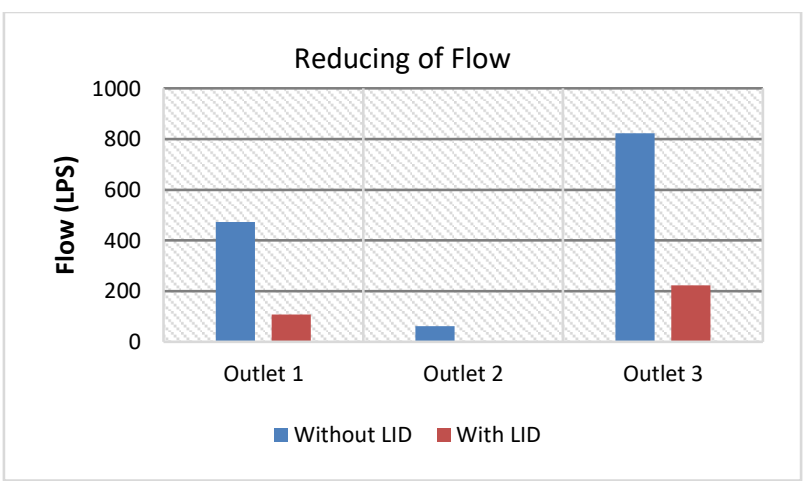

Fig. 7. Reducing Flow at Outlet 1, Outlet 2 and Outlet 3

Using the same rain as the existing conditions, the results of analysis using LID showed a significant decrease in the runoff by $77 \%$ at outlet $1,98 \%$ at outlet 2 and $73 \%$ at outlet 3 . Meanwhile, for water quality parameters, from several parameters studied namely TSS, BOD, COD, Oil \& fat, and Total Coliform showed a significant decrease ranging from $77 \%$ to $100 \%$ and almost all parameters met the quality standard, except oil and fat in all outlets, still did not meet the quality standards. While the outlet 3 parameters COD and BOD are also still slightly above the quality standard. The percentage decrease in total coliform parameters only reaches $8 \%$ to $24 \%$.

At Outlet 1, 2 and 3 points, oil \& fat parameters are still above the quality standard, while COD parameters are still above the quality standard at outlet 3 . After the application of LID for some parameters that do not meet the quality standards additional efforts are needed, such as the addition of other LID applications and the construction of WWTPs.

The location of the application of LID from the three proposed options is adjusted to the conditions of the land. Rooftop disconnection can be applied to each house by adding pipes to the roof and channeling it to areas that can absorb water. The use of land in the study location is a dense settlement so that rooftop disconnection is applied to all land, especially housing, where there is still a distance between roof wastewater and drainage channels. While permeable pavements are placed on village roads, parking lots, and land for road sidewalks. While the bioretention cell is placed on the side of the drainage channel after the storage in the full bio retention cell will flow into the drainage channel.

\section{Conclusion}

The findings of the study in the study area showed that the rainfall amounted to $7.76 \mathrm{~mm}$, water quality in the three outlet drainage outlets did not meet class 1 water quality standards, in accordance with PP No. 82 of 2001. Efforts to control runoff and pollution were carried out with several alternative LIDs including Bio- retention cell, Rain Garden, Green Roof, Permeable Pavement, Infiltration Trenches, Vegetative Swales and Rooftop Disconnection, which is a type of LID which suitable with location that can reduce runoff and pollution significantly i.e Bio-retention cell, Permeable Pavement, and Rooftop 
Disconnection. The results of the application of LID on runoff in all three outlets decreased significantly by $77 \%$ at outlet $1,98 \%$ at outlet 2 and $73 \%$ at outlet 3 . The decrease in pollutant parameters was also quite large ranging from $77 \%$ to $100 \%$ for TSS, BOD parameters, COD, Oil \& fat, while for total coliform parameters a decrease of $8 \%$ to $24 \%$.

The implementation of LID has not fully caused the quality of water to meet the specified quality standards, so that other controls are still needed, for example, processing by building wastewater treatment plant or a combination of LID and WWTP.

\section{Acknowledgments}

The author would like to acknowledge the Faculty of Engineering Diponegoro University for the support of this study with the acceptance of research proposal Grants Competing Fund Faculty of Engineering in budget 2019.

\section{References}

1. M. Yan, Modelling the fate of pollutant in overland flow, Water Research (2000)

2. M.L.R. Goncalves, J. Zischg, S. Rau, M. Sitzmann, W. Rauch, M. Kleidorfer, Modeling the Effects of Introducing Low Impact Development in a Tropical City: A Case Study from Joinville, Brazil, Sustainability (2018)

3. H. Lee, J.S. Kim, S. Jung, Flood Risk Analysis of Cultural Heritage Sites: Changgyeong Palace, Korea, Arabian Journal for Science and Engineering 39(5), 3617-3631 (2014)

4. Eric W., SandersonWilliam D., Solecki John R., Waldman Adam S., Parris. Prospects for Resilience, Springer Nature (2016)

5. R.B. Ambrose, Development of Water Quality Modeling in the United States, Environmental Engineering Research, Environ. Eng. Res. (4), 200210 (2009)

6. Rossman, A. Lewis, Storm Water Management Model Reference Manual, Water Quality III (2016)

7. LÃ $\tilde{A}^{3}$ ez, Iago, C.Ã. lvarez, J.L. Gil, A. GarcÃa, J.F. BÃ $;$ rcena, J.A. Revilla, A method for the source apportionment in bathing waters through the modelling of wastewater discharges: Development of an indicator and application to an urban beach in Santander (Northern Spain), Ecological Indicators (2013)

8. H. Lee, J. Kim, S. Jung, Flood Risk Analysis of Cultural Heritage Sites: Changgyeong Palace, Korea, Arabian Journal for Science and Engineering 39(5), 3617-3631 (2014)

9. E. Psarrou, I. Tsoukalas, C. Makropoulos, A MonteCarlo-Based Method for the Optimal Placement and Operation Scheduling of Sewer Mining Units in Urban Wastewater Networks, Water 10(2) (2018)
10. Ghodsi, S. Hamed, R. Kerachian, Z. Zahmatkesh, A multi-stakeholder framework for urban runoff quality management: Application of social choice and bargaining techniques, The Science of The Total Environment 550, 574-585 (2016)

11. A. Sarminingsih, D.S. Handayani, E. Sutrisno, B. Zaman, Evaluation The Water Availability in the Dengkeng River Due To Landuse and Climate Changes, E3S Web of Conferences 73 (2018)

12. A.R. Ipeaiyeda, P.C. Onianwa, Impact of brewery effluent on water quality of the Olosun river in Ibadan, Nigeria, Chemistry and Ecology 25 (2009) 